\title{
Measles epidemiological profile in Brasil from 2013 to 2018
}

\author{
(iD) Natália Rodrigues Costa ${ }^{1}$ \\ (D) Rafaella Menegazzo Oneda \\ (i) Cecília Albertoni Rohenkoh/1 \\ (iD) Leonardo Saraiva ${ }^{2}$ \\ (i) Luciana Kase Tanno 3 \\ (iD) Cíntia Bassani ${ }^{4,5}$
}

1. Acadêmica de Medicina do Instituto Meridional (Imed), Passo Fundo, RS, Brasil 2. Cirurgião-dentista. Mestrando em Envelhecimento Humano da Universidade de Passo Fundo (UPF), Passo Fundo, RS, Brasil 3. Division of Allergy, Department of pulmonology, University Hospital, Montpellier, France and Sorbonne University, Imserm, Iplep, Epar team, Paris, France 4. Médica pediatra, alergista e imunologista, Mestra em Ciências da Saúde pelo Hospital Servidor Público Estadual de São Paulo (lamspe), São Paulo, SP, Brasil 5. Docente do Instituto Meridional (Imed), Passo Fundo, RS, Brasil

http://dx.doi.org/10.1590/1806-9282.66.5.607

\begin{abstract}
SUMMARY
BACKGROUND: To determine the epidemiological profile of measles in Brasil from 2013 to 2018, and to evaluate the possible association between increased number of cases and vaccination coverage.

METHODS: This is an observational, descriptive, cross-sectional, retrospective study with quantitative approach, carried out through analysis of secondary data collected through the Notifiable Diseases Information System (SINAN), in the National Immunization Program (PNI).

RESULTS: The total number of reported cases was 10,886, with the year 2018 having the highest number (10,185). In the North macro-region (93.4\%), male (55.53\%), autochthonous cases from the city of residence (94.42\%) and laboratory confirmation (99.09\%) predominated. Regarding the age group, it was observed that in the period from 2013 to 2015 the highest prevalence occurred in $<1$ year, with $44.5 \%, 40.6 \%$ and $29.0 \%$, respectively, while in 2018, the highest rate was in the $20-29$ age group with $24.2 \%$. Vaccination coverage was below 95\%, except for SCR - D1 (first dose of triple viral) in the years 2013 to 2016. Regarding the outcome, there was a limited number of deaths secondary to measles (0.12\%).

CONCLUSIONS: There was an exponential growth in the number of measles cases in Brasil in 2018, which represents a public health problem. In view of this, it is necessary to implement measures such as broad vaccination coverage and sanitary control at the borders, in order to reduce the incidence of this disease and, consequently, the number of deaths.

KEYWORDS: Measles. Morbillivirus. Incidence. Emigration and Immigration. Vaccination coverage.
\end{abstract}

\section{INTRODUCTION}

Measles is an acute, transmissible and extremely infectious contagious, exanthematic disease. It is one of the major causes of morbimortality among children under five, especially in those countries where the per capita income is low, and the healthcare system is precarious. It is estimated that around $90 \%$ of

non-immune people, when exposed to an infected individual, may contract the disease ${ }^{1}$. According to the World Health Organization (WHO), more than 20 million people are vulnerable to the disease every year, and, among those, $30 \%$ have the risk of developing complications $^{2,3}$. 
Measles virus belongs to the Morbillivirus genus within the Paramyxoviridae Family ${ }^{4}$, and it spreads directly between individuals - within four days amidst rash onset, up to four days after - via airborne respiratory droplets, aerosols and direct contact with nasal and throat secretions, and/or ocular mucosa. The incubation period ranges from 10 to 14 days, when the symptoms onset $^{5,6}$. The initial symptoms (prodrome) are malaise, productive cough, ocular and nasal coryza, conjunctivitis, photophobia and growing fever - up to $40^{\circ} \mathrm{C}$ $\left(104^{\circ} \mathrm{F}\right)^{7}$.

Thus, the cervical and intra-abdominal lymph nodes can get slightly enlarged, which may lead the patient to report pain. At the end of the prodromal phase, that is, in the last 24 hours of it, Koplik spots can be seen in the premolars region: tiny white papules with a red halo - measles pathognomonic sign - which usually lasts for a short amount of time in the second phase of the disease $^{6}$. The exanthematic phase is characterized by maculopapular rash, that intersect with areas of normal skin, and is distributed in cephalocaudal direction to the extremities, lasting five to six days ${ }^{8}$. After this period, the fever declines, the rash starts to fade and a thin peeling of the skin may occur - convalescence phase ${ }^{\text {. }}$

On the other hand, measles can cause severe manifestations, depending on the viral load and on the infected individual's immune system ${ }^{3}$. Diarrhea is the most common complication, and it may lead to reduced nutritional status and to dehydration ${ }^{10}$. However, pneumonia is responsible for $5 \%$ to $10 \%$ of children's deaths ${ }^{11}$. Blindness, otitis, encephalitis, acute disseminated encephalomyelitis and subacute sclerosing panencephalitis may also occur ${ }^{12}$. It should be noted that pregnant women, when contracting the Morbillivirus during pregnancy, carry increased risk for neonatal low birth weight, fetal malformation, spontaneous abortion, intrauterine fetal death, maternal death and premature birth ${ }^{13}$.

Because of that, the Ministry of Health recommends that two blood samples must be collected between the first and the twenty-eighth day of the rash onset. Serological tests are performed in the acute phase of the disease to detect IgM antibodies in the blood and to provide viral identification. Serology is, therefore, extremely important to obtain a differential diagnosis, since diseases like rubella, exanthema subitum (roseola infantum) and scarlet fever present with similar systemic manifestations ${ }^{14}$, while viral identification detects the genetic pattern of the circulating virus in the country, differentiating the wild from vaccine-derived virus, as well as the autochthonous from exogenous cases. In order to perform the viral genotyping, the samples must be obtained until the fifth day of the rash onset, preferably within the first three days ${ }^{14}$.

There is no specific treatment to measles, only supportive measures to patients, especially to those who develop complications. The pivotal prevention and eradication measure is to vaccinate the susceptible population, and a high maintenance of vaccinal coverage is necessary - equal or greater than $95 \%$ - to reduce the possibility of the disease ${ }^{15}$. Hence, the Ministry of Health recommends the administration of a dose of the Triple Viral Vaccine (MMR - measles, mumps and rubella) at 12 months of age and a dose of Quadrivalent Vaccine (MMRV - measles, mumps, rubella and varicella) at 15 months. Nonetheless, the government recommends that during crisis periods, all children among 6 months to 11 months and 29 days should be immunized with an extra dose of MMR. Furthermore, healthcare professionals of all ages, and adults up to 29 years old are required to have two doses of the vaccine (it may be MMR or MMRV), but those older than 29 are required to have only one dose of MMR or MMRV. For those who have been exposed to the Morbillivirus, the vaccine should be given within the first 72 hours, so it can prevent the evolution of the disease and attenuate the clinical manifestations. Both the MMR and the MMRV vaccines are continuously available, for free, at the public healthcare network, in the entire country ${ }^{8,15}$.

Since the year of 1968, measles has been included, for epidemiological surveillance purposes, in the Brazilian list of compulsory notifiable diseases. In the 1980s, among the infectious contagious diseases, measles was a leading cause of death in children between one and five years old. This situation led the government to implement, in 1992, the Plan for Measles Control and Elimination, which contributed with the end of autochthonous cases, last reported in the year 2000. All the confirmed cases in Brasil since then were imported or related to import - the last one was described in 2015. Therefrom, the country received, from the Pan-American Health Organization (PAHO), the Measles Eradication Certificate, in 2016 ${ }^{\mathbf{1 6}, 17}$.

Notwithstanding, in 2019 Brasil lost the certificate, as recent data confirm the resurgence of measles in 2018. According to the Ministry of Health, Morbillivirus resurgence is due to low levels of immunization, mainly as a result of the tough geographical reach, but also because of groups with misconceptions about the 
risks of vaccination, religious and cultural beliefs, or immigration ${ }^{16,18}$.

In view of the foregoing, the research of the epidemiological profile of measles in Brasil between 2013 and 2018 is extremely relevant, considering that once the deficits in public healthcare promotion policies have been identified, measures aiming the eradication of measles and the reduction of children morbimortality in the country can be implemented.

\section{METHODS}

This is an observational, descriptive, cross-sectional, retrospective study with quantitative approach. Data regarding the period between 2013 and 2018 were collected from Notifiable Diseases Information System (SINAN), National Immunization Program (PNI) and database (sent to the author's email) generated by SUS Department of Informatics (DATASUS) in association with the Department of Immunization and Communicable Diseases (DEIDT), the technical group for exanthematic diseases and the General Coordination of the National Immunization Program (CGPNI). Through them, we could observe the relation between Brazilian macro-regions and the following variables: number of confirmed cases, sex, age, coverage of the first (VC MMR - D1) and the second (VC MMR - D2) dose of Triple Viral vaccine, coverage of the Quadrivalent vaccine (VC - MMRV), number of doses of MMR - D1, MMR - D2 and MMRV, deaths, autochthonous cases in the city of residence, which state was a source of infection and the confirmation criteria of the disease.

This research includes all the confirmed cases of measles in Brazilian macro-regions among the period of 2013 to 2018, and registered by Notifiable Diseases Information System (SINAN). The unconfirmed cases were excluded.

Statistical analysis was performed using SPSS V20, Minitab 16 and Office Excel 2010 software. Because of that, the result of each comparison has a statistical variable called de $p$-value, which simplifies tests conclusions. This research has a significance level (the probability of rejecting the null hypothesis when it is true) of 0.05 (5\%). Likewise, all of the confidence intervals in this research also met $95 \%$ of statistical confidence.

We performed the Two-Proportion Z Test, so that we could analyze the incidence of measles per 100,000 people in each macro-region, and the cases distribution of the disease in the country in each year based on sex, age, autochthonous cases of the city of residence and confirmation criteria. This test allows us to know whether the variables are valid or repeatable. We also performed the Analysis of Variance Test (ANOVA) - to compare the variance within each sample relative to the variance between the samples - so we could observe the statistical mean of vaccine coverage in each macro-region of the country among 2013 and 2018.

Finally, we performed the Pearson's correlation coefficient, a test that measures the statistical relationship or association between two continuous variables, so we could correlate the number of cases and incidence of measles to the vaccine coverage. If it is positive, when one variable increases, the other, the correlated one, will also increase. In case it is negative, the variables will be inversely proportional, which means that while one of them increases, the other will decrease, and vice-versa.

In this approach, since the data and the variables collected for this research are of public domain, and are available online at SINAN, this research is free of ethical risk, since there was no direct involvement of any individual.

\section{RESULTS}

In the years between 2013 and 2018, 10,886 cases of measles were confirmed in Brasil. Most of them were registered in $2018(n=10,185)$, followed by $2014(n=278)$, $2015(n=214)$ and $2013(n=209)$. There were no records of the disease during 2016 and 2017. When comparing the years of 2013 and 2018, we see that the incidence of measles has increased from 0.1 to 4.89 cases/100,000 people, as shown in figure 1.

Among the macro-regions, the prevalence was higher in the North $(n=10,168)$, followed by the Northeast $(n=678)$, Southeast $(n=28)$, South $(n=8)$ and, finally, the Midwest ( $n=4)$ (figure 2). However, the Northeast region had higher notification rates during the years of 2013, 2014 and 2015 ( $n=196, n=266$ e $n=211$, respectively), indicators that, in 2018, were exceeded by the 10,164 occurrences of the North region.

Regarding the distinction by sex of the population, males represented 6,045 of the cases (55.53\%), while females represented 4,841 (44.47\%) of them. The individuals $<1$ year old, in 2013, 2014 and 2015, represented the largest group of prevalence, with rates of $44.5 \%(\mathrm{n}=$ 93), $40.6 \%(n=113)$ e $29.0 \%(n=62)$ - respectively - while, in 2018, the most representative age group was between $20-29$ years old, with $24.2 \%(n=2,463)$. 


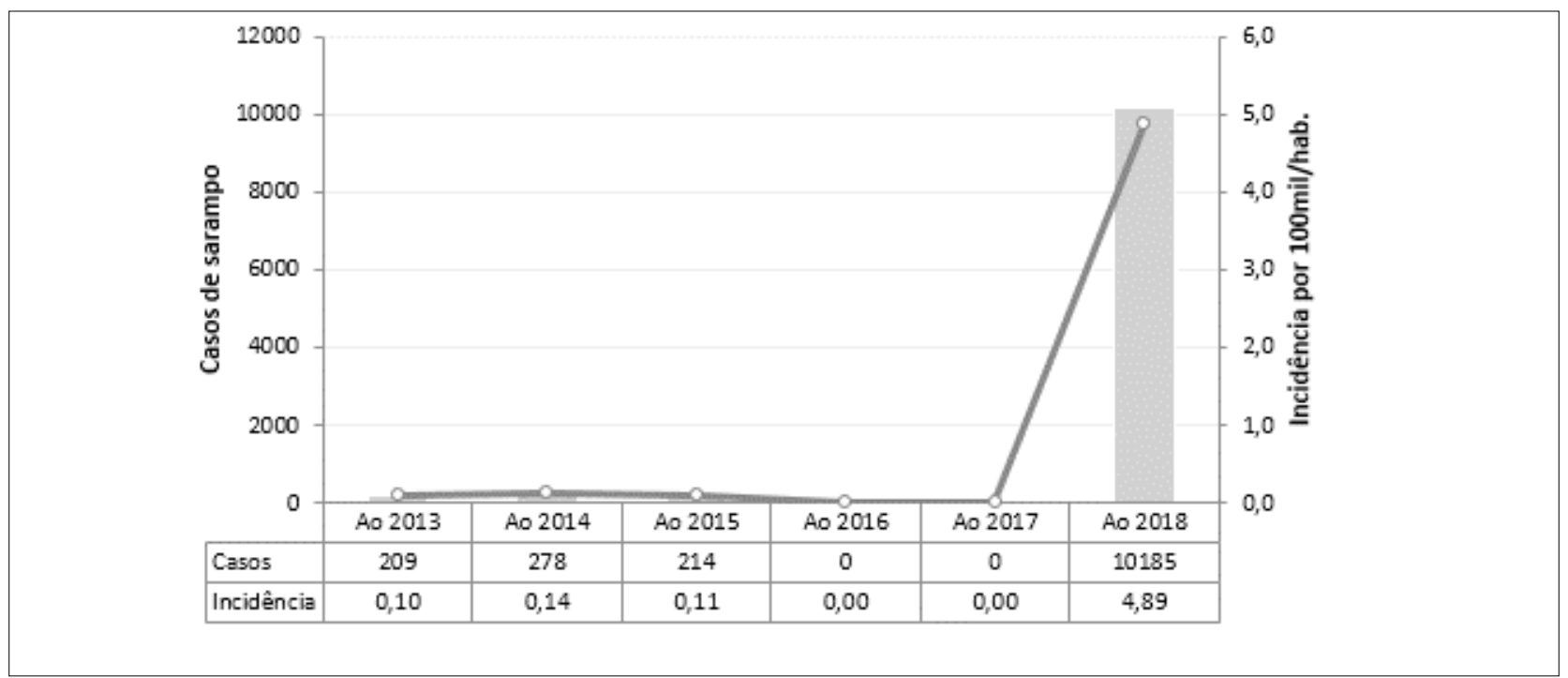

FIGURE 1. NUMBER OF CASES AND INCIDENCE OF MEASLES IN BRASIL BETWEEN 2013 AND 2018.

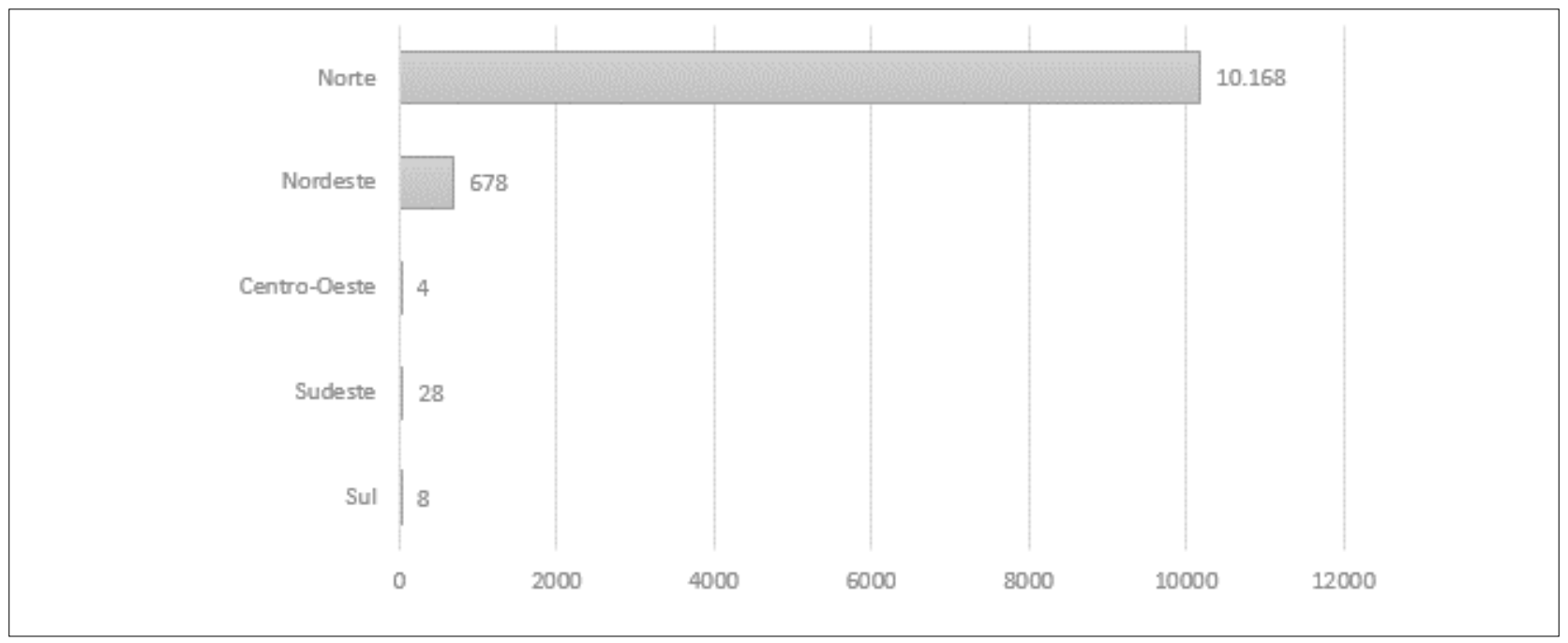

FIGURE 2. BRAZILIAN MACRO-REGIONS AND THE INCIDENCE OF MEASLES IN THE COUNTRY BETWEEN 2013 AND 2018.

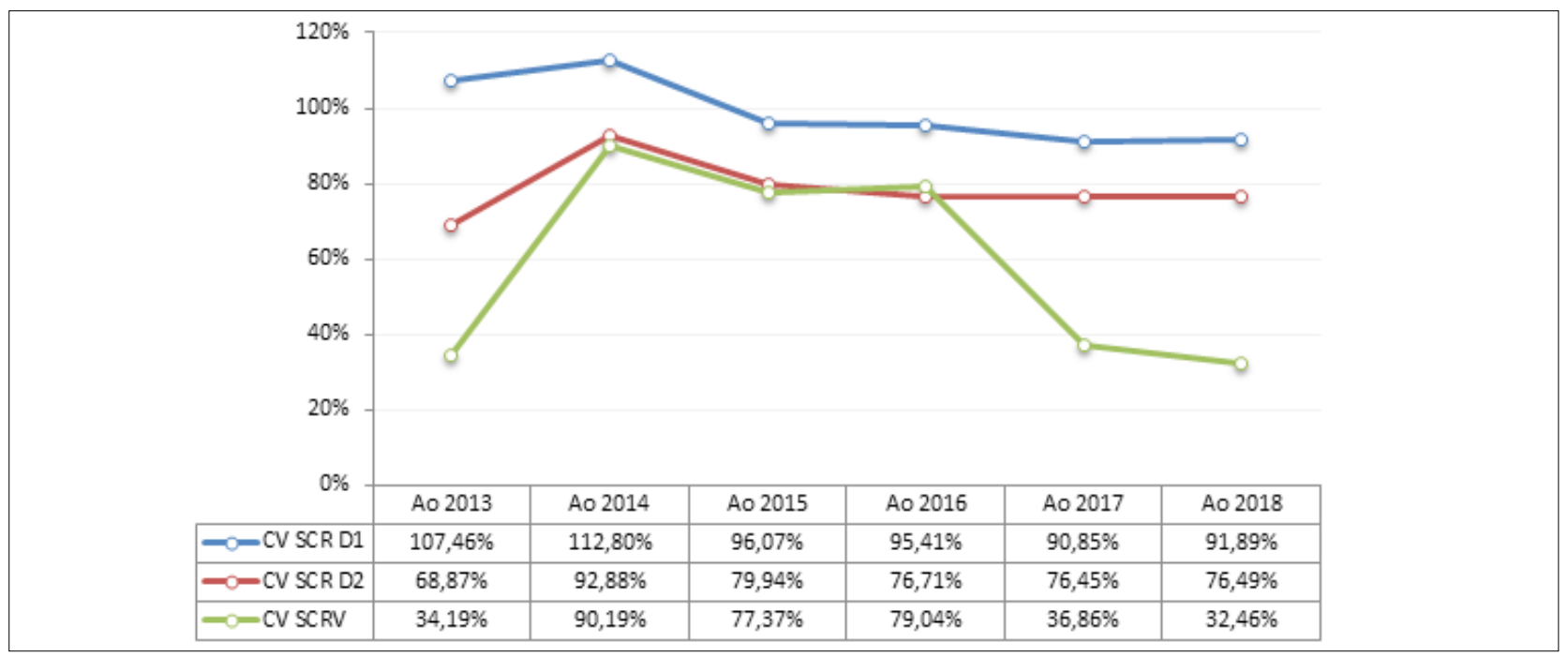

FIGURE 3. COVERAGE OF TRIPLE VIRAL AND QUADRIVALENT VACCINES IN BRASIL BETWEEN 2013 AND 2018. 
Concerning MMR - D1, MMR - D2 and MMRV vaccine coverage, each and every region showed better results in 2014, with rates of $112.8 \%, 92.88 \%$ and $90.19 \%$, respectively. In contrast, one of the worst immunization rates happened in 2018 (Figure 3).

Alongside, the relation between vaccine coverage and measles incidence does not follow a simple pattern. In 2013, while the Northeast was the macro-region with the highest rate of cases $(n=196)$, it also was the macro-region with the second-best vaccine coverage for MMR - D1 (111.99\%). In the South, region with the lowest rates of incidence $(n=1)$, the rates of immunization were considered the third best (107.25\%). During 2014, the Northeast still had the highest rates of cases $(n=266)$ and the second-best vaccine coverage (116.38\%). In comparison, Midwest had the lowest rates of incidence $(n=2)$ and the best rates of vaccine coverage (122.52\%). In 2015, the Northeast was the region with highest notification rates $(n=211)$ and it was ranked third regarding vaccine coverage (95.31\%), while the North had the lowest rates of cases $(n=1)$ and immunization (85.60\%). In 2018, an atypical year, the North region had the highest incidence rates $(\mathrm{n}=$ $10,164)$, and the lowest vaccine coverage (84.41\%), and the Northeast had the lowest rates of records $(n=5)$, and the second-best rate of immunization (93.46\%).

This research also analyzed whether the population affected by measles was autochthonous or not.

TABLE 1. SOCIODEMOGRAPHIC CHARACTERISTICS IN PATIENTS DIAGNOSED WITH MEASLES BETWEEN 2013 A 2018. $(\mathrm{N}=10.886)$

\begin{tabular}{|c|c|c|c|c|c|c|}
\hline Variables n & 2013 & 2014 & 2015 & 2016 & 2017 & 2018 \\
\hline \multicolumn{7}{|c|}{ Confirmed cases of measles } \\
\hline Brasil & 209 & 278 & 214 & 0 & 0 & 10.185 \\
\hline North & 0 & 3 & 1 & 0 & 0 & 10.164 \\
\hline Northeast & 196 & 266 & 211 & 0 & 0 & 5 \\
\hline Midwest & 2 & 2 & 0 & 0 & 0 & 0 \\
\hline Southeast & 10 & 7 & 2 & 0 & 0 & 9 \\
\hline South & 1 & 0 & 0 & 0 & 0 & 7 \\
\hline \multicolumn{7}{|l|}{ Sex } \\
\hline Male & 105 & 162 & 122 & 0 & 0 & 5.656 \\
\hline Female & 104 & 116 & 92 & 0 & 0 & 4.529 \\
\hline \multicolumn{7}{|l|}{ Age group } \\
\hline$<1$ year & 93 & 113 & 62 & 0 & 0 & 1775 \\
\hline $1-4$ years & 49 & 55 & 28 & 0 & 0 & 1179 \\
\hline $5-9$ years & 6 & 11 & 13 & 0 & 0 & 489 \\
\hline 10-14 years & 16 & 15 & 10 & 0 & 0 & 506 \\
\hline 15-19 years & 5 & 22 & 21 & 0 & 0 & 2107 \\
\hline 20-29 years & 23 & 42 & 49 & 0 & 0 & 2463 \\
\hline 30-39 years & 5 & 12 & 17 & 0 & 0 & 1068 \\
\hline $40-64$ years & 12 & 8 & 14 & 0 & 0 & 598 \\
\hline \multicolumn{7}{|l|}{ Vaccine Dose } \\
\hline MMR - D1 & 3.131 .123 & 3.276 .483 & 2.787 .903 & 2.839 .666 & 2.703 .996 & 2.622 .897 \\
\hline MMR - D2 & 2.006 .567 & 2.697 .831 & 2.319 .769 & 2.283 .169 & 2.275 .578 & 2.183 .221 \\
\hline MMRV & 996.287 & 2.619 .821 & 2.245 .170 & 2.352 .531 & 1.097 .158 & 926.437 \\
\hline Death as Evolution & 1 & 0 & 0 & 0 & 0 & 12 \\
\hline \multicolumn{7}{|c|}{ Autochthonous of the city of residence } \\
\hline Yes & 74 & 116 & 135 & 0 & 0 & 9.954 \\
\hline No & 62 & 51 & 31 & 0 & 0 & 230 \\
\hline Undetermined & 73 & 111 & 48 & 0 & 0 & 1 \\
\hline \multicolumn{7}{|l|}{ Confirmation criteria } \\
\hline Ignored/Blank & 1 & 4 & 7 & 0 & 0 & 1 \\
\hline Laboratory & 196 & 244 & 188 & 0 & 0 & 10.159 \\
\hline Clinical-epidemiological & 9 & 6 & 6 & 0 & 0 & 25 \\
\hline Clinical & 3 & 24 & 13 & 0 & 0 & 0 \\
\hline
\end{tabular}

Note: the data in this table are partial, last updated in 16-lct-2019, and subject to changes. 
We discovered that, between 2013 and 2018, there was predominance of autochthonous $(n=10,279)$, followed by imported $(n=374)$ and undetermined cases $(n=233)$. Most of the cases were diagnosed by laboratorial parameters $(n=10,787)$, followed by clinical-epidemiological $(n=46)$ and clinical criteria $(n=40)$ and Ignored/Blank $(n=13)$. The fact that the rates of laboratory parameters had always been above $87 \%$ during the analyzed period must be highlighted.

As for the outcome of measles in Brasil, most patients remained alive (99.88\%). Only 13 infected people $(n=10,886)$ died during the researched period, especially in $2013(n=1)$ and in $2018(n=12)$. Finally, Table 1 is the summary of information concerning MeV-infected citizens.

\section{DISCUSSION}

According to the World Health Organization(WHO), several countries have been facing diseases outbreaks in the last few years, and all continents are dealing with the sustained increase of measles cases ${ }^{19}$. In Europe, the number of cases increased by $300 \%$ in just one year, going from 5,273 cases in 2016, to 21,315 cases in 2017, registering 35 deaths. In the Americas, during 2017 year of a major measles outbreak in Venezuela - 272 Morbillivirus infections were confirmed, and 104 of them occurred in the country. Due to ineffectiveness in containing the transmission of the disease in 12 months, according to criteria adopted by PAHO, Venezuela has lost the Measles Eradication Certificate in $2019^{19}$.

Undoubtedly, the global resurgence of measles, after years of eradication, can be attributed to complacency with the disease, to the dissemination in Europe of misconceptions about vaccines, to a collapsed healthcare system in Venezuela, associated to intense emigration and to low rates of immunization in Africa ${ }^{20,21}$.

This research showed that, in Brasil, between 2013 and 218, 10,886 cases of measles were confirmed, and the year of 2018 had the highest incidence of the disease. This rate was much higher than the country had registered in 2015 - the last year in which the disease was reported. The Ministry of Health attributes this fact to the anti-vaccine movement, to the decrease of vaccinal coverage in recent years, and to viral importation ${ }^{16}$.

It is also worth mentioning that after the implementation of the Plan for Measles Control and Elimination in Brasil, in 1992, the disease presented endemic behavior and had epidemic peaks every two to three years. In 2013, the state that confirmed the most cases was Pernambuco $(\mathrm{n}=108)$, and in 2014 and 2015, it was Ceará $(n=141$ and $n=165$, respectively). Due to surveillance and immunization actions, no more measles reporting had occurred until 2018, when imported cases triggered severe outbreaks in Roraima $(\mathrm{n}=355)$, Amazonas $(\mathrm{n}=9.778)$ and other states, but with lower prevalence ${ }^{16,18}$.

Regarding viral characterization, the D8 genotype - the same one that is circulating in Venezuela - was identified in all states in 2018, except for a notification in Rio Grande do Sul (genotype B3 - circulating virus in Europe) and another in São Paulo (genotype D8 and infected person with a history of travel to Lebanon). Thus, it can be implied that the current outbreak in the country may be related to immigration and/or emigration. In addition, both Venezuela's and Northern Brasil's vaccination coverage are below 95\%, percentage recommended by the WHO for group immunization to happen, facts that could facilitate measles virus infection ${ }^{1,21}$.

Another point concerns the distribution of confirmed measles cases by sex, in which men were the most affected, with $55.53 \%$ of notifications. This result is similar to that found by Lemos ${ }^{10}, 58.6 \%$, and also by Coelho and Rivemales ${ }^{14}, 64 \%$. There is still no relevant factor to explain the large difference between the number of infected men and women, however, Lemos ${ }^{10}$ believes that males tend to neglect their health, which leads to the immunization goal not being met by males.

Regarding the age group, we noticed that, between 2013 and 2015, the highest occurrence of measles happened in children $<1$ year. We believe that this may be related to the neglect of immunization, mainly due to the mistaken perception that measles had been eradicated, besides to the lack of confidence in the safety of the vaccines and its erroneous association with autism, a connection refuted by studies ${ }^{22}$. However, in 2018, the highest prevalence was between the 20-29 years age group, with $24.2 \%$ rates. We attribute this to the fact the this population have only received one dose of the triple viral vaccine, once the Ministry of Health introduced the second dose of MMR, which offers protection around $97 \%$, only in $2004^{23}$.

The research also showed a gradual reduction in MMR - D1 vaccination coverage from 2014 to 2017. In 2018 , though, there was an increase of $1.04 \%$. Nevertheless, it is possible to identify a reduction in the proportionality of MMR - D1 vaccination coverage, as there 
was a decrease of $8.81 \%$ in the period from 2013 to 2018. WHO considers ideal immunization the one with values above $95 \%$. From this number, it is considered that a group immunization is created, which also protects the unvaccinated. If the unvaccinated people exceed $8 \%$, they become a risk factor for everyone else. Based on this research, we can see that between 2017 and 2018, the coverage of Triple Viral and Quadrivalent vaccines in Brasil was below the recommended by $\mathrm{WHO}^{16}$.

Although insufficient coverage was noted, the present study did not find any statistical significance in correlating case-incidence and immunization rate. Nevertheless, we assumed that the $8.81 \%$ reduction in vaccine coverage may be related to the increase in the number of cases in the country.

The detection of autochthonous cases in the city of residence was observed in $94.4 \%$ of the confirmations, which differs from the pattern analyzed by Faversani et al. ${ }^{24}$, in which Brasil has not reported this type of occurrence since 2000. Similar to other studies ${ }^{4,10}$, in order to validate measles cases - from 2013 to 2018 the laboratory diagnostic criteria (99.09\%) was used. These criteria are essential, since it allows the detection of IgM/IgG antibodies and the identification of the genetic pattern of the circulating $\mathrm{MeV}$ in the country - differentiating the wild from the vaccine-derived virus, and the autochthonous from the imported ones.

Most of the infected citizens evolved to the cure (99.88\%), while only $0.12 \%$ died due to complications of the disease. As to location, four deaths occurred in Roraima (two Brazilians and two Venezuelans, all $<5$ years old) and six in Amazonas (four in $<1$ year old and two in the 40-64 old age group) - three residents in Manaus, two in Autazes and one in Manacapuru. In Pará, two deaths occurred in the city of Belém, both indigenous Venezuelans $<1$ year old ${ }^{18}$.

Zaidi et al. ${ }^{3}$ found that the risk of developing measles complications is $30 \%$, with the highest incidence in children under five years old and adults over twenty years old. The results of the present research are consistent with the ones about death age found by Zaidi et al. ${ }^{3}$. In addition, another study published in Science Journal ${ }^{25}$, indicated that children and adults infected with $\mathrm{MeV}$ become immunosuppressed for a period, since measles causes immunological amnesia of $20 \%$ to $70 \%$ of the antibody repertoire of these people, leading loss of the immunity developed for other pathogens in the past. Thus, they are more susceptible to secondary infections and, consequently, to complications and death ${ }^{25}$.
As a limitation of the study, we highlight the secondary source of data, which may present lack of case notifications, which often ends up making some information and statistical correlations unfeasible. Nevertheless, both SINAN and PNI are essential tools for maintaining epidemiological control.

\section{CONCLUSION}

The epidemiological analysis demonstrated that between the period from 2013 to 2018, 10,886 cases of measles were confirmed in the country, and the highest incidence of the disease, in 2018, erupted in the North region, with predominance of genotype D8 - similar to the genetic sequencing circulating in Venezuela. The age group $<1$ year old stood out from 2013 to 2015. However, in 2018, it was the 20-29 years old that was prominent. In addition, there was a male predominance among those infected by measles virus - autochthonous of the city of residence, laboratory diagnosis, evolution to the cure and insufficient vaccination coverage rates $(<95 \%)$ of both Triple Viral and Quadrivalent vaccines, in most of the years analyzed.

Based on this context, is it stated that the only way to prevent and eradicate Morbillivirus is through vaccination. Thus, it is essential to highlight the relevance of active immunity, especially in children under 1 year old, and in people born until 2004. Moreover, the high flow of immigrants may have contributed to the reintroduction of $\mathrm{MeV}$ into Brazilian territory, therefore, sanitary control should be increased and vaccination intensified at borders in order to prevent further cases of the disease and, consequently, more deaths.

\section{Acknowledgment}

To the Institute Meridional (IMED) and the Hospital do Servidor Público of São Paulo (HSPE).

\section{Author contributions}

Natália Rodrigues Costa: Conceptualization, Data curation, Formal analysis, Investigation, Methodology, Software. Rafaella Menegazzo Oneda: Formal analysis, Resources, Writing-original draft. Cecília Albertoni Rohenkohl: Methodology, Resources, Writing-original draft. Leonardo Saraiva: Conceptualization, Methodology, Writing-review \& editing. Luciana Kase Tanno: Supervision, Writing-review \& editing. Cintia Bassani: Conceptualization, Supervision, Writing-original draft 


\section{RESUMO}

OBJETIVO: Determinar o perfil epidemiológico do sarampo no Brasil no período de 2013 a 2018, além da possível correlação entre incidência de casos e cobertura vacinal.

MÉTODO: Trata-se uma pesquisa observacional, com delineamento descritivo, transversal, retrospectivo e com abordagem quantitativa, feita por meio de análises de dados secundários coletados no Sistema Nacional de Agravos de Notificação (Sinan), no Programa Nacional de Imunizações (PNI).

RESULTADOS: O total de casos confirmados foi 10.886, sendo o ano de 2018 com o maior número (10.185). Predominou a macrorregião Norte (93,4\%), sexo masculino (55,53\%), casos autóctones do município de residência (94,42\%) e confirmação laboratorial (99,09\%). Com relação à faixa etária, observou-se que, no período de 2013 a 2015, a maior prevalência ocorreu em $<1$ ano, com 44,5\%, 40,6\% e $29,0 \%$, respectivamente, enquanto que, em 2018 , o maior índice foi na faixa de $20-29$ anos, com $24,2 \%$. A cobertura vacinal ficou abaixo de 95\%, exceto a SCR - D1 (primeira dose da tríplice viral) nos anos de 2013 a 2016. Quanto ao desfecho, houve limitado número de óbitos secundários ao sarampo (0,12\%).

CONCLUSÃo: Verifica-se um crescimento exponencial no número de casos de sarampo no Brasil em 2018, o que representa um problema de saúde pública. Diante disso, carece que medidas como ampla cobertura vacinal e controle sanitário, nas fronteiras, sejam implementadas, a fim de reduzir a incidência dessa enfermidade e, consequentemente, o número de óbitos.

PALAVRAS-CHAVE: Sarampo. Morbillivirus. Incidência. Emigração e imigração. Cobertura vacinal.

\section{REFERENCES}

1. Brasil. Ministério da Saúde. Situação do sarampo no Brasil - 2018. [cited 2019 Nov 12]. Available from: https://portalarquivos2.saude.gov.br/images/ pdf/2018/julho/19/Informe-Sarampo142.pdf

2. World Health Organization. Press release: WHO warns of increased risk of disease epidemics in Syria and in neighbouring countries as summer approaches, 3 June 2013. [cited 2019 Nov 12]. Available from: http://www. emro.who.int/press-releases/2013/disease-epidemics-syria.html

3. Zaidi SSZ, Hameed A, Ali N, Rana MS, Umair M, Alam MM, et al. Epidemiological and molecular investigation of a measles outbreak in Punjab, Pakistan, 2013-2015. J Med Virol. 2018;90(8):1297-303.

4. Palminha P, Vinagre E, Cordeiro R, Ribeiro C, Roque C. Diagnóstico laboratorial do sarampo em Portugal, 2011-2013. Instituto Nacional de Saúde. 2015;6(7):17-20. [cited 2019 Nov 12]. Available from: http://repositorio. insa.pt/bitstream/10400.18/3240/3/observacoesNEspecia6-2015_artigo6. pdf

5. European Centre for Disease Prevention and Control (ECDC). Rapid risk assessment: risk of measles transmission in the EU/EEA. [cited 2019 Nov 12]. Available from: https://www.ecdc.europa.eu/sites/default/files/documents/Measles-rapid-risk-assessment-European-Union-countries_0.pdf

6. Zenner D, Nacul L. Predictive power of Koplik's spots for the diagnosis of measles. J Infect Dev Ctries. 2012;6(3):271-5.

7. Ballalai I, Michelin L, Kfouri R. Sarampo: diagnóstico, notificação e prevenção. [cited 2019 Nov 12]. Available from: https://www.sbp.com.br/ fileadmin/user_upload/NOTA_TECNICA_CONJUNTA_SBIM-SBP_ SBI-_sarampo-jul18__002_.pdf

8. Sociedade Brasileira de Pediatria. Atualização sobre sarampo. [cited 2019 Nov 12]. Available from: https://www.sbp.com.br/imprensa/detalhe/nid/ atualizacao-sobre-sarampo/

9. Kuschnaroff T, Focaccia R. Sarampo. In: Veronesi R, Focaccia R, eds. Tratado de infectologia. 5a ed. São Paulo: Atheneu; 2015. p.875-82.

10. Lemos DRQ. Epidemia de sarampo no Ceará no período pós-eliminação nas Américas: enfrentamento, resposta coordenada e avaliação de risco para reintrodução do vírus [Tese de Doutorado]. Fortaleza: Universidade Estadual do Ceará; 2016.

11. World Health Organization. Measles vaccines: WHO position paper. Weekly Epidemiological Record. 2009;35(35):349-60. [cited 2019 Nov 12]. Available from: https://www.who.int/wer/2009/wer8435.pdf?ua=1

12. Zeng SZ, Zhang B, Zhang Y, Xie LY, Xiong I, Yu T, et al. Identification of 12 cases of acute measles encephalitis without rash. Clin Infect Dis. 2016;63(12):1630-3.

13. Ogbuanu IU, Zeko S, Chu S, Muroua C, Gerber S, De Wee R, et al. Maternal, fetal, and neonatal outcomes associated with measles during pregnancy:
Namibia, 2009-2010. Clin Infect Dis. 2014;58(8):1086-92.

14. Coelho LMG, Rivemales MCC. Doenças exantemáticas no Distrito Sanitário Barra/ Rio Vermelho (DSBRV) no período de 2003 a 2007. Rev Baiana Saúde Pública. 2009;33(4):509-21.

15. Brasil. Ministério da Saúde. Secretaria de Vigilância em Saúde, Departamento de Vigilância das Doenças Transmissíveis. Plano de contingência para resposta às emergências de saúde pública: sarampo. [cited 2019 Nov 12]. Available from: http://bvsms.saude.gov.br/bvs/publicacoes/plano_contingencia_resposta_emergencias_sarampo.pdf

16. Ribeiro C, Menezes C, Lamas C. Sarampo: achados epidemiológicos recentes e implicações para a prática clínica. Almanaque Multidisciplinar de Pesquisa. 2015;1(2):4-16.

17. Brasil. Ministério da Saúde. Brasil recebe certificado de eliminação do sarampo. Brasília: Ministério da Saúde; 2016. [cited 2019 Oct 19]. Available from: http://saude.gov.br/noticias/ agencia-saude/25846-brasil-recebe-certificado-de-eliminacao-do-sarampo

18. Brasil. Ministério da Saúde. Situação do sarampo no Brasil - 2019. Brasília: Ministério da Saúde; 2019. [cited 2019 Oct 19]. Available from: https:// portalarquivos2.saude.gov.br/images/pdf/2019/janeiro/28/Informe-Sarampo-n36-24jan19aed.pdf

19. Secretaria de Saúde do Ceará. Boletim epidemiológico: doença exantemática. 2019. [cited 2019 Oct 19]. Available from: https://www.saude. ce.gov.br/wp-content/uploads/sites/9/2018/06/boletim_exantematica_20_03_2018.pdf

20. Robert A, Funk S, Kucharski A). The measles crisis in Europe: the need for a joined-up approach. Lancet. 2019;393(10185):2033.

21. Page KR, Doocy S, Reyna Ganteaume F, Castro JS, Spiegel P, Beyrer $C$. Venezuela's public health crisis : a regional emergency. Lancet. 2019;393(10177):1254-60.

22. Fadda GM, Cury VE. O enigma do autismo: contribuições sobre a etiologia do transtorno. Psicol Estudo. 2016;21(3):411-23.

23. Brasil. Secretaria de Vigilância em Saúde. Sarampo: atualização da Semana epidemiológica 34. Brasília: Secretaria de Vigilância em Saúde; 2019. [cited 2019 Oct 19]. Available from: https://portalarquivos2.saude.gov.br/ images/pdf/2019/setembro/02/3.\%20a\%20-\%202019_08_29\%20-\%20 SARAMPO\%20-\%20CIT.pdf

24. Faversani MCSS, Kupek E, Westrupp MHB. Perfil epidemiológico do sarampo no estado de Santa Catarina, Brasil, de 1996 a 2000. Cad Saúde Pública. 2005;21(2):535-44.

25. Mina MI, Kula T, Leng Y, Li M, Vries RD, Knip M, et al. Measles virus infection diminishes preexisting antibodies that offer protection from other pathogens. Science. 2019;366(6465):599-606. 